$\mathrm{DE}$

M E D I C I N A

T R O P I C A L

$\mathrm{DE}$

S ÃO PAULO

JOURNAL OF THE SÃO PAULO INSTITUTE OF TROPICAL MEDICINE

(1)Universidade de São Paulo, Faculdade de Medicina, Hospital das Clínicas, Ambulatório de Imunodeficiência Secundária, São Paulo, São Paulo, Brazil

(2)Universidade de São Paulo, Faculdade de Medicina, Disciplina de Reumatologia, Laboratório de Metabolismo Ósseo São Paulo, São Paulo, Brazil

(3)Universidade de São Paulo, Faculdade de Medicina, Laboratório de Investigação Médica em Neurologia (LIM 56), São Paulo, São Paulo, Brazil

(4)Universidade de São Paulo, Instituto de Medicina Tropical de São Paulo, São Paulo, São Paulo, Brazil

${ }^{(5)}$ University of California, Global Health Sciences, San Francisco, California, USA

(6)Universidade de São Paulo, Faculdade de Medicina, Departamento de Medicina Preventiva, (LIM 38), São Paulo, São Paulo, Brazil

(7) Universidade Federal do Rio de Janeiro, Cursos de Nutrição, Rio de Janeiro, Rio de Janeiro, Brazil

Correspondence to: Jorge Casseb Universidade de São Paulo, Instituto de Medicina Tropical de São Paulo, Av. Dr. Enéas de Carvalho Aguiar, 470, CEP 05403-000, São Paulo, SP, Brazil. Tel.: +55 11 3061-7194, Fax: +55 11 30817190

E-mail: jcasseb@usp.br

Received: 21 July 2016

Accepted: 10 October 2017

\section{Low bone mineral density among HIV-infected patients in Brazil}

Daniela Cardeal da Silva Chaba ${ }^{1,3,5}$, Lisméia R. Soares ${ }^{7}$, Rosa M. R. Pereira ${ }^{2}$, George W. Rutherford ${ }^{5}$, Tatiane Assone $^{3}$ Liliam Takayama $^{2}$, Luiz A. M. Fonseca $^{6}$, Alberto J. S. Duarte ${ }^{1}$, Jorge Casseb ${ }^{1,3,4}$

\section{ABSTRACT}

Decrease in bone mineral density (BMD) has been a complication among people living with HIV/AIDS. To investigate the prevalence of osteopenia/osteoporosis among HIV-infected people living in São Paulo city, we studied $108 \mathrm{HIV}$-infected patients (79 men and 29 women). We extracted data from patients' medical records and BMD was measured by dual-energy $\mathrm{X}$-ray absorptiometry (DXA). Median age of participants was 42 years (interquartile range [IQR] 36-48 years), and the median time since HIV diagnosis was 4.01 years (IQR 2-11 years). Patients had acquired HIV primarily by the sexual route (men who have sex with men 44\%, heterosexual 49\%). Median age, duration of HIV infection, duration of ART and CD4 nadir were similar for men and women. Plasma viral load was undetectable for 53 patients $(49 \%)$. Median CD4 T cell count was 399 cells/ $\mu \mathrm{L}$ (IQR 247 - 568). Twenty five patients (23\%) had LBMD, and there was no statistically significant difference between men and women $(<-1)$. The associated risk factors for LBMD were older age ( $\geq 50$ years old) and smoking with a RR of 3.87 and 2.80, respectively. Thus, despite the lack of statistically significant relationship between the use of ART and LBMD or between duration of ART and LBMD, these factors should be addressed in larger studies.

KEYWORDS: HIV. Bone mineral. Osteoporosis. Risk factors.

\section{INTRODUCTION}

The HIV-infected population has aged, especially when engaged long-time survival, even in developing countries, such as Brazil, which have adopted universal access to ART since middle 90 's ${ }^{1}$.One of these new challenges is the chronic metabolic disturbances, such as diabetes, hypertension, metabolic syndrome and deregulation of bone metabolism².

The pathogenesis of bone demineralization in HIV infection is unclear ${ }^{3}$. Possible explanations include a direct action of the infection itself $f^{4}$, an untoward effect of the antiretroviral therapy (ART) ${ }^{5}$, a deregulation of bone metabolism as a result of the T-CD4 cell depletion ${ }^{6}$, or a consequence of other risk factors for osteoporosis that are more prevalent among people with HIV such as poor nutrition or smoking ${ }^{7}$. Identifying modifiable risk factors may be the key for designing simple interventions and preventing significant clinical morbidity.

In a middle-income country such as Brazil, bone demineralization is an important cause of morbidity, even in the absence of HIV infection. For example, from 2006 to $2008,1 \%$ of all patients aging 60 years old and older who were hospitalized in the Unified National Health System (SUS) had a primary diagnosis of hip fracture, 
and they accounted for $2 \%$ of health care expenditures ${ }^{8}$. The mean cost of hospitalization for a hip fracture is $\$ 12,000$ in the Brazilian private health care system ${ }^{9}$. Thus, as the HIV-infected population ages as a result of successful $\mathrm{ART}^{10,11}$, osteopenia and osteoporosis, both of them effects of HIV infection and aging, have the potential to become substantial public health burdens ${ }^{12}$, and their prevention becomes an important public health goal. We studied the prevalence of low bone mineral density (LBMD), and risk factors in a population of $108 \mathrm{HIV}$-infected patients under follow-up at a referral center in São Paulo, Brazil.

\section{MATERIAL AND METHODS}

\section{Subjects}

The study population was composed of HIV-1-infected patients attended at the outpatient clinic for secondary immunodeficiencies of Hospital das Clínicas, University of São Paulo Medical School (HC/FMUSP), São Paulo, SP, Brazil, a large teaching and research hospital. This open patient cohort was composed of 455 active HIV1-infected subjects under follow-up for up to 16 years. Description of the cohort and its characteristics have been published elsewhere ${ }^{13,14}$. All patients were invited to participate, 108 accepted. The study protocol was approved by the Hospital das Clínicas Review Board and all patients gave written informed consent.

\section{Predictor variables}

Our predictor variables included sex, age, time since HIV diagnosis, CD4 cells/ $\mu \mathrm{L}, \mathrm{CD} 4$ nadir, plasma viral load, current use of ART, body mass index [BMI], current smoking status and physical activity. These variables were extracted from clinical charts. For analyzes, we dichotomized the age into $\leq 50$ years and $>50$ years, CD4 count into $<350$ cells $/ \mu \mathrm{L}$ and $\geq 350$ cells $/ \mu \mathrm{L}, \mathrm{CD} 4$ nadir into $<170$ cells $/ \mu \mathrm{L}$ and $\geq 170$ cells $/ \mu \mathrm{L}$, time since HIV diagnosis into $<4$ years and $\geq 4$ years, plasma viral load into detectable or non-detectable and time on ART as $\leq 5$ years or $>5$ years. However, classes of ART drugs were not considered in detail on this report, therefore, no further information for their use is provided in the report.

\section{Bone mineral density measurement and categorization}

Our primary outcome variable was LBMD, which we measured using dual X-ray absorptiometry of the lumbar spine, femoral neck and total hip (Hologic, QDR 4500, Discovery model, Hologic Inc. Bedford, MA, USA).
All measurements of bone mineral density (BMD) were performed by the same experienced technician (LT). We classified post-menopausal women and men $\geq 50$ years old as having osteoporosis or osteopenia based on World Health Organization criteria. Subjects with a BMD T-score between -1 and -2.5 were categorized as having osteopenia, and subjects with a BMD T-score less than or equal to -2.5 were categorized as having osteoporosis. For the purposes of this study, any participant with osteopenia or osteoporosis according to the WHO definition wasconsidered to have LBMD. This classification has been extensively used by other authors ${ }^{5,15-17}$.

\section{Statistical analysis}

We calculated the prevalence of LBMD with $95 \%$ confidence intervals (CI), and evaluated the association of LBMD with its potential risk factors by calculating the relative risks.

\section{RESULTS}

We enrolled 108 patients of whom 78 (72\%) were men and $30(28 \%)$ were women. The median age was 43 years (interquartile range [IQR]: 43 - 48), and the median BMI was $24 \mathrm{~kg} / \mathrm{m}^{2}$ (IQR: $22-27$ ). LBMD was detected in $15 \%$ (95\% CI: 6 - 22) of patients younger than 50 years old and $54 \%$ (95\% CI: $32-77$ ) of those who were 50 years old and older. The median follow-up period from the date of HIV infection diagnosis was 4 years (95\% CI: 2- 11); $74 \%$ of the patients were on ART for a median time of 5.12 years (IQR: 2.59 - 10.12). The median CD4 counts and median nadir for CD4 counts were 399 cells/ $\mu \mathrm{L}$ (IQR: 275 - 566.5) and 176.5 cells/ $\mu \mathrm{L}$ (IQR: 73 - 309), respectively. Participants enrolled in the study did not differ significantly from the remainder of patients followed in the Hospital das Clinicas cohort (Table 1).

The overall prevalence of LBMD was $23.15 \%$ (95\% CI, $15.06-31.23 \%$ ), of them 15 (60\%) HIV-1-infected had osteopenia and 10 (40\%) HIV-1-infected had osteoporosis. The risk of LBMD was higher in subjects $>50$ years of age $(14.45 \%$ vs. $54.54 \%$, RR $3.77,95 \%$ CI, $1.97-7.02$, $\mathrm{p}=0.001)$, those with $\mathrm{T}$ CD 4 counts $<350$ cells $/ \mu \mathrm{L}(15.87 \%$ vs. $33.33 \%$, RR $2.1,95 \%$ CI 1.03-4.24, $\mathrm{p}=0.03$ ) and current smokers (39.28\% vs. $17.94 \%$, RR $2.18,95 \%$ CI $1.12-4.23$, $\mathrm{p}=0.02)$ (Table 2).

\section{DISCUSSION}

We found that the overall prevalence of LBMD in our patients who had been on ART for a median of 5 years was 
$23.15 \%$. Previous studies have estimated that the prevalence of osteopenia and osteoporosis in Brazilian patients with

Table 1 - Demographic, clinical and behavioral characteristics according to low BMD, among 108 HIV-infected patients attending an outpatient HIV clinic, São Paulo, Brazil

\begin{tabular}{|c|c|c|}
\hline \multirow{2}{*}{$\frac{\text { Variables }}{\text { LBMD }}$} & \multicolumn{2}{|c|}{$\mathrm{N}=108$ patients } \\
\hline & 25 & $23.15 \%$ \\
\hline \multicolumn{3}{|l|}{ Gender } \\
\hline Female & 30 & $(27.78 \%)$ \\
\hline Male & 78 & $72.22 \%$ \\
\hline Age median (IQR) & 43,17 & $43.17-48.19$ \\
\hline$>50$ Years & 22 & $20.37 \%$ \\
\hline$\leq 50$ years & 83 & $76.86 \%$ \\
\hline \multicolumn{3}{|l|}{ HIV transmission } \\
\hline Homosexual & 50 & $46 \%$ \\
\hline Heterosexual & 54 & $50 \%$ \\
\hline Others & 4 & $3.70 \%$ \\
\hline T CD4 cells Median (IQR) & 399 & $275-566.5$ \\
\hline$\leq 350$ cells $/ \mathrm{mm}^{3}$ & 45 & $41.67 \%$ \\
\hline$\leq 350$ cells $/ \mathrm{mm}^{3}$ & 45 & $41.67 \%$ \\
\hline Nadir median (IQR) & 176,5 & 73-309 \\
\hline$<170$ cells $/ \mathrm{mm}^{3}$ & 50 & $46.30 \%$ \\
\hline$\geq 170$ cells $/ \mathrm{mm}^{3}$ & 58 & $53.70 \%$ \\
\hline Time since HIV diagnostic (IQR) & 3,66 & $1.72-10.91$ \\
\hline$>4$ years & 49 & $45.37 \%$ \\
\hline$\leq 4$ years & 55 & $50.93 \%$ \\
\hline \multicolumn{3}{|l|}{ Viral load } \\
\hline Detectable & 52 & $48.15 \%$ \\
\hline Undetectable & 53 & $49.09 \%$ \\
\hline \multicolumn{3}{|l|}{ Under ART } \\
\hline Yes & 80 & $74.07 \%$ \\
\hline No & 28 & $25.93 \%$ \\
\hline \multicolumn{3}{|l|}{ Years under ART } \\
\hline$>5$ years & 41 & $51.25 \%$ \\
\hline$\leq 5$ years & 36 & $45 \%$ \\
\hline \multicolumn{3}{|l|}{ Smoking } \\
\hline Yes & 28 & $25.93 \%$ \\
\hline No & 78 & $72.22 \%$ \\
\hline \multicolumn{3}{|l|}{ Physical Activity } \\
\hline No & 72 & $66.67 \%$ \\
\hline Yes & 34 & $31.48 \%$ \\
\hline \multicolumn{3}{|l|}{ BMI } \\
\hline$\leq 25$ & 54 & $50 \%$ \\
\hline$>25$ & 35 & $32.41 \%$ \\
\hline
\end{tabular}

HIV infection was $54.5 \%{ }^{5}$. This discrepancy could be related to different methodologies used in these studies, thus leading to these discordant results.

The CD4 cell count $<350$ cells $/ \mu \mathrm{L}$ which was a risk factor for LBMD had not been previously reported and may indicate that the longer the duration of infection or the less successful the ART, the higher the likelihood of developing LBMD. Additionally, we did not find a statistically significant relationship between the use of ART and LBMD or between the duration of ART and LBMD, although both relationships have been already reported ${ }^{18,19}$. As mentioned before, osteoporosis was associated with HIV infection duration, low current or low nadir CD4 cell count or high viral load, for example ${ }^{20}$. Cazanave et $a l .{ }^{21}$ showed that low nadir CD4 lymphocyte count was independently associated with osteoporosis/osteopenia in women, demonstrating that these alterations were induced by early bone demineralization.

In fact, HIV-infected infected subjects have lower BMI than HIV-negative control groups, as described previously ${ }^{22}$. Several reports demonstrated that habit of smoking, and lifestyle, traditional known risk factors for osteoporosis, are also important in this population ${ }^{23,24}$. Furthermore, reduced BMD was also significantly associated with low 25-hidroxy-calciferol in this cohort ${ }^{25}$. Thus, smoking reduction, physical activity ${ }^{26}$ and other life changes may have an impact on bone disease.

Our study was limited by its small sample size, which may have led to a type II error. Larger and more regularly sampled cohorts may yield different results. Nonetheless, our findings are compelling and suggest that addressing modifiable risk factors for LBMD and fractures might constitute important interventions as Brazilian HIV-infected patients age, especially for those who are already older than 50 years old.

\section{ACKNOWLEDGMENTS}

The first author (DC) received support through the University of California San Francisco from U.S. National Institutes of Health (NIH) Fogarty International Center (FIC), D43TW005799 and National Institute of Mental Health (NIMH) International Traineeships in AIDS Prevention Studies (ITAPS), R25MH064712, and HIV Research Trust Scholarship (HIVRT), HIVRT11-074. The content is solely the responsibility of the authors and does not necessarily represent the official views of the NIH, NIMH, FIC, or HIVRT. We all thank the patients who participated in this study. We also thank Claudio Gonsalez, Marcelo Mendonça, Eduardo Lago Negro, Sandra Matta and Stephanie Sales for their clinical assistance. 
Table 2 - Risk factors for low BMD among HIV-infected patients attending an outpatient HIV clinic, São Paulo, Brazil

\begin{tabular}{|c|c|c|c|c|c|c|}
\hline Characteristic & All & $\begin{array}{l}\text { LBMD } \\
\text { present }\end{array}$ & $\begin{array}{c}\text { LBMD } \\
\text { not present }\end{array}$ & $\begin{array}{l}\text { Probability of hav- } \\
\text { ing LBMS given } \\
\text { characteristic }\end{array}$ & $\mathrm{RR}$ & P Value \\
\hline \multicolumn{7}{|l|}{ Gender } \\
\hline Female & $30(27.8)$ & $7(28.0)$ & $23(27.6)$ & 0.230 & $1(0.46-2.12)$ & 0.97 \\
\hline Male & $78(72.2)$ & $18(72.0)$ & $60(72.3)$ & 0.230 & & \\
\hline \multicolumn{7}{|l|}{ Age } \\
\hline$>50$ years old & $25(23.2)$ & $12(50.00)$ & $10(12.4)$ & 0.545 & $3.78(1.97-7.02)$ & 0.001 \\
\hline$\leq 50$ years old & 83 (76.9) & $12(50.0)$ & $71(87.7)$ & 0.144 & & \\
\hline \multicolumn{7}{|l|}{ CD4 ${ }^{+} \mathrm{T}$ cells $/ \mu$} \\
\hline$\leq 350 \mathrm{CD}^{+}{ }^{+} \mathrm{T}$ cells $/ \mu$ & $45(41.7)$ & $15(60.0)$ & $30(36.1)$ & 0.333 & $2.10(1.03-4.24)$ & 0.003 \\
\hline$>350 \mathrm{CD}^{+}{ }^{+} \mathrm{T}$ cells $/ \mu$ & $63(58.3)$ & $10(40.0)$ & $53(63.9)$ & 0.158 & & \\
\hline \multicolumn{7}{|l|}{ Nadir CD4 } \\
\hline$<170 \mathrm{CD}^{+}{ }^{+} \mathrm{T}$ cells $/ \mu$ & $50(46.3)$ & $9(36.0)$ & $41(49.4)$ & 0.18 & $0.47(0.31-1.43)$ & 0.23 \\
\hline$\geq 170 \mathrm{CD} 4^{+} \mathrm{T}$ cells $/ \mu$ & $58(53.7)$ & $16(64.0)$ & $42(50.6)$ & 0.38 & & \\
\hline \multicolumn{7}{|c|}{ Time since HIV diagnosis } \\
\hline$>4$ years & $49(47.1)$ & $13(54.2)$ & $42(52.5)$ & 0.54 & $1.03(0.46-1.92)$ & 0.88 \\
\hline$\leq 4$ years & 55 (52.9) & $11(45.8)$ & $38(47.5)$ & 0.52 & & \\
\hline \multicolumn{7}{|l|}{ Plasma HIV RNA } \\
\hline Detectable & $52(49.5)$ & $12(50.0)$ & $40(49.4)$ & 0.50 & $1.02(0.50-2.05)$ & 0.95 \\
\hline Undetectabe & $53(50.5)$ & $12(50.0)$ & $41(50.6)$ & 0.49 & & \\
\hline \multicolumn{7}{|l|}{ On ART } \\
\hline Yes & $80(74.1)$ & $21(84.0)$ & $59(71.1)$ & 0.84 & $1.18(0.69-4.89)$ & 0.19 \\
\hline No & $28(25.9)$ & $4(16.0)$ & $24(28.9)$ & 0.71 & & \\
\hline \multicolumn{7}{|l|}{ Years on ART } \\
\hline$>5$ & $41(52.6)$ & $11(55.0)$ & $30(51.7)$ & 0.55 & $1.10(0.51-2.35)$ & 0.20 \\
\hline$\leq 5$ & $37(47.4)$ & $9(45.0)$ & $28(48.2)$ & 0.51 & & \\
\hline \multicolumn{7}{|l|}{ Smoking } \\
\hline Yes & $28(26.4)$ & $14(56.0)$ & $17(21.0)$ & 0.56 & $2.8(1.12-4.23)$ & 0.02 \\
\hline No & $78(73.6)$ & $11(44.0)$ & $64(79.0)$ & 0.20 & & \\
\hline \multicolumn{7}{|l|}{ Physical activity } \\
\hline Not physically active & $72(67.9)$ & $11(44.0)$ & $23(71.6)$ & 0.44 & $1.66(0.84-3.27)$ & 0.14 \\
\hline Physically active & $34(32.1)$ & $14(56.0)$ & $58(28.4)$ & 0.71 & & \\
\hline \multicolumn{7}{|l|}{$\mathrm{BMI}, \mathrm{kg} / \mathrm{m}^{2 *}$} \\
\hline$\leq 25$ & $54(60.7)$ & $18(75.0)$ & $36(55.4)$ & 0.75 & $1.94(0.85-4.41)$ & 0.09 \\
\hline$>25$ & 35 (39.3) & $6(25.0)$ & $29(44.6)$ & 0.55 & & \\
\hline
\end{tabular}

LBMD, low bone mineral density; HIV, human immunodeficiency virus; RR, relative risk; Cl, confidence interval; BMI, body mass index; ART, antiretroviral therapy; ${ }^{*} 19$ missing values

\section{REFERENCES}

1. Malta M, da Silva CM, Magnanini MM, Wirtz AL, Perissé AR, Beyrer C, et al. Improvement of HAART in Brazil, 19982008: a nationwide assessment of survival times after AIDS diagnosis among men who have sex with men. BMC Public Health. 2015;15:226.
2. Langkilde A, Petersen J, Klausen HH, Henriksen JH, EugenOlsen J, Andersen O. Inflammation in HIV-infected patients: impact of HIV, lifestyle, body composition, and demography - a cross sectional cohort study. PloS One. 2012;7:e51698.

3. Cotter AG, Sabin CA, Simelane S, Macken A, Kavanagh E, Brady JJ, et al. Relative contribution of HIV infection, 
demographics and body mass index to bone mineral density. AIDS. 2014;28:2051-60.

4. Schafer JJ, Manlangit K, Squires KE. Bone health and human immunodeficiency virus infection. Pharmacotherapy. 2013;33:665-82.

5. Pinto Neto LF, Ragi-Eis S, Vieira NF, Soprani M, Neves MB, Ribeiro-Rodrigues R, et al. Low bone mass prevalence, therapy type, and clinical risk factors in an HIV-infected Brazilian population. J Clin Densitom. 2011;14:434-9.

6. Yong MK, Elliott JH, Woolley IJ, Hoy JF. Low CD4 count is associated with an increased risk of fragility fracture in HIVinfected patients. J Acquir Immune Defic Syndr. 2011;57:205-10.

7. Eleftheriou KI, Rawal JS, James LE, Payne JR, Loosemore M, Pennell DJ, et al. Bone structure and geometry in young men: the influence of smoking, alcohol intake and physical activity. Bone. 2013;52:17-26.

8. Bortolon PC, Andrade CL, Andrade CA. O perfil das internações do SUS para fratura osteoporótica de fêmur em idosos no Brasil: uma descrição do triênio 2006-2008. Cad Saude Publica. 2011;27:733-42.

9. Araújo DV, Oliveira JH, Bracco OL. Custo da fratura osteoporótica de fêmur no sistema suplementar de saúde brasileiro. Arq Bras Endocrinol Metabol. 2005;49:897-901.

10. Nunn AS, Fonseca EM, Bastos FI, Gruskin S, Salomon JA. Evolution of antiretroviral drug costs in Brazil in the context of free and universal access to AIDS treatment. PLoS Med. 2007;4:e305.

11. Grinsztejn B, Luz PM, Pacheco AG, Santos DV, Velasque L, Moreira RI, et al. Changing mortality profile among HIVinfected patients in Rio de Janeiro, Brazil: shifting from AIDS to non-AIDS related conditions in the HAART era. PloS One. 2013;8:e59768.

12. Young B, Dao CN, Buchacz K, Baker R, Brooks JT. Increased rates of bone fracture among $\mathrm{HIV}$-infected persons in the HIV Outpatient Study (HOPS) compared with the US general population, 2000-2006. Clin Infect Dis. 2011;52:1061-8.

13. Casseb J, Fonseca LA, Medeiros LA, Gonsalez CR, Lagonegro ER, Veiga AP, et al. Tuberculosis among HIV-1-infected subjects in a tertiary out-patient service in Sao Paulo city, Brazil. Rev Inst Med Trop Sao Paulo. 2012;54:257-9.

14. Alcalde R, Guimarães ML, Duarte AJ, Casseb J. Clinical, epidemiological and molecular features of the HIV-1 subtype $\mathrm{C}$ and recombinant forms that are circulating in the city of Sao Paulo, Brazil. Virol J. 2012;9:156.

15. Bonjoch A, Figueras M, Estany C, Perez-Alvarez N, Rosales J, del Rio L, et al. High prevalence of and progression to low bone mineral density in HIV-infected patients: a longitudinal cohort study. AIDS. 2010;24:2827-33.

16. Bow CH, Tsang SW, Loong CH, Soong CS, Yeung SC, Kung AW. Bone mineral density enhances use of clinical risk factors in predicting ten-year risk of osteoporotic fractures in Chinese men: the Hong Kong Osteoporosis Study. Osteoporos Int. 2011;22:2799-807.

17. Baim S, Binkley N, Bilezikian JP, Kendler DL, Hans DB, Lewiecki EM, et al. Official Positions of the International Society for Clinical Densitometry and executive summary of the 2007 ISCD Position Development Conference. J Clin Densitom. 2008;11:75-91.

18. Brown TT, Qaqish RB. Antiretroviral therapy and the prevalence of osteopenia and osteoporosis: a meta-analytic review. AIDS. 2006;20:2165-74.

19. Brown TT, Qaqish RB. Response to Berg et al. 'Antiretroviral therapy and the prevalence of osteopenia and osteoporosis: a meta-analytic review'. AIDS. 2007;21:1830-1.

20. Zhang N, Gui Y, Qiu X, Tang W, Li L, Gober HJ, et al. DHEA prevents bone loss by suppressing the expansion of CD4(+) $\mathrm{T}$ cells and TNFa production in the OVX-mouse model for postmenopausal osteoporosis. Biosci Trends. 2016;10:277-87.

21. Cazanave C, Dupon M, Lavignolle-Aurillac V, Barthe N, LawsonAyayi S, Mehsen N, et al. Reduced bone mineral density in HIV-infected patients: prevalence and associated factors. AIDS. 2008;22:395-402.

22. Chitu-Tisu CE, Barbu EC, Lazar M, Ion DA, Badarau IA. Low bone mineral density and associated risk factors in HIVinfected patients. Germs. 2016;6:50-9.

23. Jones S, Restrepo D, Kasowitz A, Korenstein D, Wallenstein S, Schneider A, et al. Risk factors for decreased bone density and effects of HIV on bone in the elderly. Osteoporos Int. 2008;19:913-8.

24. Yin M, Dobkin J, Brudney K, Becker C, Zadel JL, Manandhar $\mathrm{M}$, et al. Bone mass and mineral metabolism in HIV+ postmenopausal women. Osteoporos Int. 2005;16:1345-52.

25. Sales SH, Matta SM, da Silva DC, Assone TA, Fonseca LA, Duarte AJ, et al. High frequency of deficient consumption and low blood levels of 25-hydroxyvitamin D in HIV-1-infected adults from Sao Paulo city, Brazil. Sci Rep. 2015;5:12990.

26. Soares LR, da Silva DC, Gonsalez CR, Batista FG, Fonseca LA, Duarte AJ, et al. Discordance between body mass index and anthropometric measurements among HIV-1-infected patients on antiretroviral therapy and with lipoatrophy/lipohypertrophy syndrome. Rev Inst Med Trop Sao Paulo. 2015;57:105-10. 